\title{
Application of Multiple Intelligence Theory to Increase Student Motivation in Learning History
}

\author{
Abdul Razaq Ahmad ${ }^{1}$, Ahmad Ali Seman², Mohd Mahzan Awang ${ }^{1}$ \& Fadzilah Sulaiman ${ }^{1}$ \\ ${ }^{1}$ Faculty of Education, Universiti Kebangsaan Malaysia, Malaysia \\ ${ }^{2}$ Faculty of Social Sciences \& Humanities, Universiti Kebangsaan Malaysia, Malaysia \\ Correspondence: Abdul Razaq Ahmad, Universiti Kebangsaan Malaysia, 43600 UKM Bangi, Selangor, Malaysia. \\ E-mail: razaq@ukm.edu.my
}

Received: September 29, 2014 Accepted: October 13, $2014 \quad$ Online Published: November 17, 2014

doi:10.5539/ach.v7n1p210

URL: http://dx.doi.org/10.5539/ach.v7n1p210

\begin{abstract}
This study aimed at investigating the enhancement of motivation among low achievement students in the History lesson, after the multiple intelligence theory was integrated in teachers' teaching practices. The teachers were expected to apply a new approach with various teaching activities to motivate students to learn. The sample consisted of 68 low achievement students, who were then divided into two groups: 34 students were treated in the treatment group, while another 34 students were put in the control group. This is a quasi-experiment of non equivalent control group design. The questionnaire was distributed to students of both groups, to test the effectiveness of the integration approach. Analysis of the mean and standard deviation was conducted for both groups, while the null hypothesis was tested by the t- test. Based on the pre-test, there was no significant difference between the two groups. The post-test recorded significant motivational differences between the two groups studied. It was determined that the integrated History lesson with multiple intelligences had increased the level of motivation among students in the treatment group. This shows that diversity of methods and activities undertaken were able to change students' perception about the History subject and had increased their interests to learn History. Hence, it can be concluded that integrated multiple intelligence activities are able to increase students' motivation to learn History.
\end{abstract}

Keywords: multiple intelligence, student motivation, readiness, History subject

\section{Introduction}

\subsection{Background}

The History subject for the secondary school was upgraded as a core subject at par with other subjects namely Malay Language, English, Mathematics, Science and Islamic/Moral Studies. This is due to the fact that History subject has been recognized as a vital subject to develop great personality and identity among Malaysian students. The cultural elements in the History curriculum should be able to raise students' curiosity and the contents could be intelligently delivered by the subject teacher as interesting topics to be debated by students. A creative teaching and learning process would encourage students' interest and motivate them to learn the subject.

The common approach of teaching History lesson has been critised as too conventional and teacher-centred. The teaching and learning sessions were mostly dominated as one man show by teacher; students were not given fair opportunities to develop their talents and abilities. According to Abdul Rahim (1989), the common teaching approaches emphasize the rote methods; hence fail to exploit one's thinking skills, making the subject to be too dry, static and boring. The rote learning method disables students to participate actively and there is no ample opportunity for students to interpret, analyze and evaluate the learning materials. As a result, historical information is accepted as a rigid and unquestionable doctrine.

This calls for desperate measures and great efforts in developing historical thinking as it is crucial in improving learning performance and encouraging explorative learning. Despite extensive efforts have been made to improve the quality of teaching in schools, yet there are issuess need to be resolved through a variety of approaches. Past studies revealed that without teachers' creativity in learing History subject, students will have a lack of interest to learn certain subjects (Omardin \& Yunus, 1996; Baghaei \& Riasati, 2013). It will be terrible if students are forced to memorise names of prominent figures, dates and events without understanding the purpose and reasons of doing 
so. Historical events are not to be memorized but to be understood. One-way teaching method is outdated and does not provide chances for students to interact and expand their thinking. Low performance students in terms of cognitive behaviours are poor in the context of reading, reasoning and learning strategies (Meichenbaum \& Biemiller, 1998; Lawrance \& Vimala, 2012). These problems distrupt their learning process and disable them to achieve good performance in the teaching and learning environment. Hence, this group of students need helps particularly in developing their cognitive skills. Scholars in History Education suggested that the best effort is by treating their academic aspect through a variety, yet appropriate teaching methods (Bruer, 1993; Ahmad, Awang, Seman \& Abdullah, 2013).

This study is to investigate the impact of applying Multiple Intelligences theory in the History lesson, particularly in enhancing teaching and learning quality. It is also to see its effectiveness in changing the outdated and negative stigma commonly associated with History lesson. The application of new approach should make the lesson to be more dynamic, interesting and should be able to activate students' learning process. The theory of multiple Intelligences was developed by Gardner $(1983,1999)$ who proposed ten types of intelligences namely naturalist, verbal-linguistic, spatial, kinesthetics, musical, logical-mathematics, interpersonal, intrapersonal, naturalist, spiritual and existential. Gardner $(1983,1999)$ has identified eight different types of potential intelligences possessed by each individual. These potentials need to be revealed in order to produce excellent students and those with great performances. A static teaching for instance would dampen students' latent talents and competencies especially their intrapersonal. In fact, it distorts the process of generating ideas, experience and students' interpersonal skills. Teachers should know that interactions, activities and active participation would provide amazing learning experience and would bring out all of the potentials owned by students.

This theory is vital in enhancing one's dignity and creativity; it has the ability to motivate students through a fun teaching and learning experience. This is due to the fact that each individual has the capacity to learn something effectively if his dominant intelligence is manipulated properly. Hence, this study is to determine the effectiveness of this theory when it is applied in the teaching and learning History subject, as well as to see how it helps in improving students' historical knowledge, experience, acquisition and motivation.

\subsection{Research on Teaching Practices and Students' Achievement}

Extensive past studies on students' achievement in academic subjects have been carried out in the past. A study of students' academic achievement conducted by Awang et al. (2013) revealed that students' academic performance has a close relationship with their motivation in school. Many studies in the past suggest that low achievement students are too dependent on others for helps in all of their learning affairs (Phillips, 1993; Jacobson \& Burdsal, 2012). Their views on learning situations are also shallow and negative, full with stress and tension. They consider themselves as incapable to meet the teachers' needs with their learning environment, resulting to low self-esteem and low self-confidence. Those feelings are their worst enemies especially when they experience interpersonal disturbances.

This view is supported by Griffin (1978), Lepper, Pintrich \& De Groot (1990), Corpus \& Iyengar (2005), Atta and Jamil (2012) who stated that students who frequently fail in their academic records would have low motivation, restless, uncertain and having unpredictable behaviours. They are unable to focus in class and having difficulty to generate ideas in producing systematic and precise answers. Learning motivation among students can be measured by their explicit behaviours. There is a significant gap between motivated and unmotivated students. Unmotivated students normally have the tendency to skip classes, play truant, unable to complete tasks and assignments given by the teachers, unable to focus in class and during the learning contacts which consequently cause them to have bad results.

Sadly, they have negative perception towards the learning process; they are not serious, clueless and indifferent towards their bad performance. They commonly have the tendency to cheat in completeng their school works, and during the examinations (Sakhilah 1998; Wahab, Mansor, Awang \& Ayob, 2013).

Wan Rafaei (1977), Gottfried (1985), Atta and Jamil (2012) had conducted a of low achievers where findings showed that the majority of students had a low level of learning motivation. This is due to the lack of external motivations to encourage them to be be more commited in learning academic subjects. A similar study was conducted by Titi (2007) and Renganathan (2013) regarding the impacts of Jigsaw III cooperative learning towards motivation and achievement in Mathematics. Results of the study revealed that there was a significant difference of mean score for the aspects of motivation and achievement.

According to Davies (1975) and Dunlosky et al. (2013) the most significant characteristic showed by these low achievers is they have a very slow and limited ability to memorise things. They often forget the things they have learnt, because all of the information is stored in their short-term memory and then dispatched from their memory box. This is due to their negligent and irresponsible attitudes. High (1977) and and Dunlosky et al. (2013) 
suggested that these students need rote learning using effective techniques or activities such as mind mapping, key words, mnemonics, games, cross-word puzzles, timeline, role play and visual aids.

\section{Objectives}

This study aimed to explore the impacts of applying the theory of multiple intelligences to motivate form two low achievement students in the aspect of academic achievement. The students were considered as low achievers and at the shaky position either to fail or to pass in the History subject. The objectives of the study are to measure significant differences of learning motivation between both control and treatment groups, as well as to see the changes in learning behavior pre and post treatment sessions.

\section{Methods}

The current study utilized a quasi experiment. The experiment group was treated with a new teaching method by applying multiple intelligence theory, whereas the control group was taught in the same conventional method.

Table 1. Quasi experiment

\begin{tabular}{llll}
\hline Group & Pre-Test & Methods & Post-Test \\
\hline Treatment & 01 & $\mathrm{X} 1$ & 03 \\
Control & 02 & $\mathrm{X} 2$ & 04 \\
\hline
\end{tabular}

X1: Application of MIT in the teaching and learning process.

$\mathrm{X} 2$ : Conventional lesson

01, 02: Pre-test

03, 04: Prost-test.

This study aimed to explore the impacts of applying the theory of multiple intelligences to motivate form Two students in the aspect of academic achievement. The students were considered as low achievers and at the shaky position either to fail or to pass in the History subject. The objectives of the study were to measure significant differences of learning motivation between both control and treatment groups, as well as to see the changes in learning behavior pre and post treatment sessions.

This study investigated the impact of adopting new teaching approach by applying multiple intelligence teaching methods to motivate low achievement students in the treatment group. It was to witness positive changes of interest to learn. According to Sugiyono (2007), the quasi-experiment uses a control group as the benchmark of changes against behavioral changes experienced by students in the treatment group. Pre-test and post-test were designed and used to evaluate pre and post tests, as well as its level of effectiveness. This method of study enabled the researchers to evaluate the extent of its effectiveness with the outcomes of students' own learning. According to Yin (1989), research design would reflect the research purpose and objectives, determine the data and its analysis methods.

\subsection{Population and Samples of the Study}

The population involved form two students who were considered as low achievers in the History subject from two secondary schools in Cheras, Selangor. Sample is part of the population carefully chosen to represent the whole population (Dickinson \& Lee, 1978; Creswell, 2005). The sample of this study was randomly selected based on the research zones in order to selects representatives from the selected districts and schools. This sampling method will fairly represent each characteristic of the population (Stake, 2005; Borg \& Gall, 1989).

68 students were purposely selected from the whole two available classes. The classes were chosen based on achievement grades, age, IQ and the same History subject learnt by the students at the time of the study. 34 students were grouped in the treatment group and the History subject was taught by applying multiple intelligences. Whereas, another 34 students were put in the control group and they learnt the subject conventionally.

\subsection{Instruments}

Pre and post tests were used as the main instruments to measure students' knowledge and their achievement. A questionnaire to determine motivation was also used to examine the changes of students' motivation. Items of the questionnaire were built based on the pre-determined constructs. The items were adopted from the Motivates Strategies for Learning Questionnaire (MSLQ) designed by Pintrich (1990), research findings by Roslan (2007), 
Salwani (2003) and Abdul Hakim (2004). Results of the pilot study which were based on the Alpha Cronbach showed in overall the instrument was reliable at the reliability level of 0.8653 .

\section{Findings and Discussion}

The motivation level of students in the treatment group showed a significant increase when compared with students in the control group. Results of the inference analysis showed that students in the treatment group experienced changes and there were significant differences of their motivation towards the History teaching pre and post treatment. However, the level of motivation among students in the control group remained unchanged before and after the lesson, as the interpretation of the mean scores did not show any different. Due to that, it can be concluded that integrated History teaching and learning lessons particularly by using multiple intelligences method have influenced and increased students' motivation in learning the subject. The new integrated approach involved activities which required students to use their multiple intelligences; hence this provoked thier interests to learn more and to like the subject. This statement is supported by the Centre of Curriculum Development of Malaysia stated that the application was able to enhance students' self-esteem, creativity and motivation through fun learning.

Findings showed that students in the treatment group experienced positive changes in the motivational aspect. This is in line with the findings of a research conducted by Gottfried (1985) and Awang, Ahmad and Ali (2013) who stated that internal motivation on academic affairs have positive correlation with students' achievement and positive behaviour. Positive attitudes and high motivation towards learning are two elements which able to influence students' interest to learn (Nor Zaiton, 2006; Awang, Ahmad, \& Ali, 2013; Awang et al., 2013). Students in the treatment group indeed experienced positive changes in their motivation to learn History; this is a solid proof that application of various teaching methods in the History lesson would help students to generate their latent potentials. Students started to realise their own natural talents and potentials. All this while most of them were clueless and neglect their own strenght, which was then revealed by the method used and encouraged them to change.

Integrated teaching and learning activities such as drawing, dramatizing, role modelling, and mind mapping, arouse students' interests to learn History subject as those activities are student-centred. Those activities demand students' participation in the class, and according to Adleer (1984), students' level of motivation would be increased if they were given autonomy to control their own learning pace. For example, verbal linguistic intelligence can be stimulated by using graphic management activities, when students are encouraged to read for more information in order to complete a graphic management. This hiddenly, improves students reading skills. As a result, their interests are aroused and they are more motivated to learn more.

Apart from that, body kinesthetic intelligence can be stimulated through activities such as role modelling and drama to revisit historical events, which require students to move their body. Students would surely be excited to take part in such activities and they would want to know more of the subject. Interpersonal intelligence provides great opportunity for students to discuss with friends and share each other's knowledge through group discussions. Thus, it is proven by the students in the treatment group that a change of the instructional methods and application of integrated multiple intelligences have positive impacts on students. The learning process was fun and beneficial for the students.

Table 2. Comparison of Mean scores and standard deviation of motivation in pre and post tests

\begin{tabular}{lccccc}
\hline \multirow{2}{*}{ Group } & \multirow{2}{*}{ Number } & \multicolumn{2}{c}{ Pre-test } & \multicolumn{2}{c}{ Post-test } \\
\cline { 3 - 6 } & & Mean & S.D & Mean & S.D \\
\hline Treatment & 34 & 3.34 & 0.62 & 4.51 & 0.29 \\
Control & 34 & 3.18 & 0.68 & 3.18 & 0.69 \\
\hline
\end{tabular}

Analisys of the t-test conducted on both groups showed there were significant differences between both groups in terms of the level of their motivation. Students in the treatment group showed higher level of motivation compared to students who were in the control group who did not show any difference in their level of motivation. The change of motivation is referred to students' behaviours, which in this case of study, they were more positive and their interest to learn History has increased. This was impacted by the amount of teacher's classroom domination and the opportunities given to the students to show their talents, abilities and creativities during the History lesson.

Academic intervention through this application has proven having positive impacts on students' internal motivation for a better change. Academic treatment can be considered as an approach to improve students' cognitive skill and 
arouse their interest to learn (Bruer, 1993).Multiple intelligence method taps student's potential in various aspects, showing that students' internal motivation to learn can be enhanced via many ways using multiple approaches. The positive motivational changes among students towards teaching and learning History subject have proven that tapping students' potentials through multiple intelligences has helped students to be more active.

According to Stipek (1988), Corpus and Iyengar (2005), Atta and Jamil (2012), there are many ways to enhance students' internal motivation, such as by giving tasks appropriate to students' ability. It is a bonus if the tasks are instructed creatively, conducted in a small group interaction and students are given ample opportunities to control their own learning pace. Findings of this study have shown that students in the treatment group showed an increase of their motivation to learn after they were treated by the new teaching method.

Findings of this study are supporting the results of a research conducted by Saifuddin (1997) and Fischer \& Virgillito (2012) which found that motivation is vital in improving students' academic performance. Therefore, they need continous encouragement to sustain their level of motivation for it to contribute to academic achievement. A classical research carried out done by Entwistle and Wilson (1970) found that good and systematic learning methods together with high motivation are some of the elements closely related to academic achievement and personality. The recent study on the same subject has also revealed the same result (Abbas \& Khurshid, 2013; Hasan, Hamzah \& Awang, 2014). Shahabuddin et al. (2007) concluded the same opinion that motivational phase is the first phase of one learning process.

Learning process will be meaningless and ineffective without the motivation to learn. Motivation is a dynamic force to encourage someone to keep on working and learning (Lepper, Corpus\& Iyenger, 2005; Shahabuddin et al., 2007; Abbas \& Khurshid, 2013). In line with that study, the present study showed that low achievement students could improve their learning and academic performance, provided that they are taught by using various creative strategies, together with innovatice and comprehensive teaching approaches. The best way is by integrating teaching and learning strategies with multi-methods, the activities are best embedded in the lesson by involving multiple intelligences.

This study contributes meaningfully to the implementation of instructional process at schools, by providing new ideas on how to implement an integrated teaching process with the multiple intelligence elements. Every teacher should realise that each student has their own potential to be tapped in order to improve their performance. Sadly, students themselves do not realise their own potential, thus, it is teachers' responsibility to tap the potential through a series of actions and class activities.

Introduction of new approaches in the learning and teaching context should be implemented for the benefits of students. For instance, stimulating activities should be suitable with students' needs, and their level of understanding particularly those low achievers who need more encouragement. Due to that, applying the multiple intelligence elements in the normal lesson would make the lesson to be more alive and vibrant, together with student-centred activities to activate the learning session.

This study also revealed that a learning process would be meaningless and deem ineffective if the History subject is taught in a conventional manner. It calls for change and improvement. Teachers should possess abundance of knowledge and motivation to develop their simple teaching and learning sessions to be more fun and interesting learning experience for the students.

Students' potentials can be enhanced in every teaching and learning session. Spontaneous question and answer session is a good practice to develop verbal-linguistic skills. Drilling on the other hand, promotes personal change towards dramatic achievement. The process of learning involves social interaction; therefore interpersonal skills can be developed through well-structured and interesting activities. Teachers can level up the patterns and types of relationship among students, and teachers can encourage students to actively interact with them by providing incentive and rewards. Low achievement students can not be forced or pressured, but they need encouragement to learn which can be achieved through fun, enjoyable, relax and interesting learning session. A bit of musical elements such as slide shows and audio visual in learning will also help to improve learning capacity.

This study also contributes ideas for teachers that natural elements from the surrounding can also be used as one of active learning aspects. Teachers should not restrict themselves with a simple understanding that teaching and learning can only be done in the classrooms. External sorrounding of the classroom is also a good location for learning, it even brings new influence, and the fresh open surrounding would excite the students with new learning experience. Among external environments which are great outdoor locations for learning to take place are the school garden, the hall, the laboratories, resource centre, media room and at the field. 
Intrapersonal factors are the backbone of learning. It is undeniable that inner factors are vital in improving students' performance; the factors are indeed the major impulses. Therefore, teachers should know how to manipulate students' internal factors in order to increase the effects of instructional process particularly to change students' behaviours in terms of cognitive, affective and pyschomotor.

\section{Implications and Recommendations}

This study has revealed that it is important for teachers to think out of the box in order to help students to "free" themselves from any close-mindedness. This is because learning can only take place when students can independently learn things by themselves, free to explore and when they are trained to tap their own potentials. Such opportunities should be provided by teachers to increase students' interest and to motivate them to learn the History subject.

This study also contributes to the new information regarding learning motivation among low achievement students. They actually have their own potential but often neglected either by themselves or most probably by the teachers. Hence, teachers should provide interesting and meaningful learning experience. Learning History can be fun if students' previous knowledge is successfully tapped and generated by the teacher in explaining historical events, especially if the students are given ample chances to explore the events themselves, of course under the teacher's supervision as a facilitator.

Results of this study explain how students who were categorised as low achievers should receive information and use the historic information for their own benefits. In fact, their potentials should be generated form every aspect - space, language, verbal, interpersonal and intrapersonal skills. This will ease the learning process and students can definitely absorb information better and able to clearly imagine those historical events that they have learnt in class.

It is proven by this study that every child has multiple intelligence elements which is vital in improving the effectiveness of history lessons. Teachers should efficiently use storyline and develop teaching materials by relating past events with current situations to arouse students' curiosity to know more details of a certain event. As a result, they would have empathatic learning and would interact effectively with the learning aids.

According to the Curriculum Development Centre (2001), successful application of the multiple intelligence theory in class would ensure that the learning objectives can be attained. This is because students are actively involved in the learning process, for example through group activities to identify information, translate teaching aids, and evaluate information. Contents of a lesson can be evaluated by rationale, imaginative and innovative thinking. Hence, it is unsurprising that low achievement students are able to improve their achievement and their learning performance, of course with teachers' efforts who integrated their lessons with the theory of multiple intelligences.

Teachers need to plan their lesson well, to embed multiple intelligences with several topics of the lesson. Teachers also need to have extra sources of knowledge regarding the current teaching and learning strategies, particularly to encourage students to think and develop their thinking skills. A good lesson should be one which is more students-centred, flexible and fun. For instance, when teaching the subsistence farming topic, teacher can tap students' previous knowledge about the types of rural farming through brainstorming activity, and questioning session on the impacts of economic activities introduced by the colonists on the progress of the country. Teacher can test students' general knowledge relevant to the history of economic development by showing them the logos of notable estates conglomerates such as Guthrie and Sime Darby in relation with the government agency particularly the Federal Land Development Authority (FELDA)

It is undeniable that musical elements are very much relevant to the teenagers at large. Thus, it is great if teachers use those elements to help their students to understand History through the national anthem Jalur Gemilang or the song about the homeland Malaysia Tanah Airku. The melody and lyrics of songs can develop several feelings and emotion. In addition, they can generate many ideas to be associated with nation-building. This creates a free, fun yet meaningful new learning experience. Successful application of these History lesson plans will be able to tap students' latent potentials, and students will genuinely understand historical information. In fact, this type of understanding would help students to digest and understand the information with open heart and open mind.

Student-centred approach unintentionally encourages students to develop their thinking skills through activities such as group discussions, analysing historical documents, observing teaching aids and illustrating thinking map or completing written exercises. Such activities are very beneficial to develop almost all multiple intelligences or amazing abilites possessed by the students, for example kinesthetic skills, verbal-linguistic, logic/mathematics, spatial, interpersonal, intrapersonal and naturalist. 
This new integrated approach encourages students to learn harder, it reduces distraction and enhances students' commitment to focus on their lesson and learning materials. At the same time, it reduces teachers' energy as they no longer need to talk alone doing a one-man show, yet ineffective.

Information from this study would help teachers to understand that the main goal of learning is not how the lessons are structured but the contents are more beneficial and able to modify students' behaviours, produce measureable learning products, and increase students' interest to learn History. The most important is, students should know and fully understand not only the contents but also how to master the learning materials. Then, students should be able to transfer the knowledge whether in a matter of structured answers, in paragraphs or multiple-choice questions.

Due to that, teachers should act more as facilitators in guiding students individually, making them understand easily and giving them the skills to learn History, without the need to shout. This can best be achieved through an integrated approach particularly by using students' multiple intelligence; at the same time students are taught how to learn history. All of those can easily be achieved by integrating all of the intelligences discussed previously.

Teaching History with integrated multiple intelligence is an alternative to help low performance students improve their achievement. It is recognised and proven as a way to change students' behaviours. Creative activities integrated with multiple intelligence elements bring new light and new dimension to learning situations. In achieving learning objectives, students are no longer bound with rigid instructions but they are directed to independent learning where they have to search and explore information on their own, using various appropriate methods.

In addition, this new approach brings postive implications towards students and teachers. It is proven by this study that, tapping students' multiple intelligence would help low achievers to achieve better results and improve their performance. The learning session is very significant not only in the cognitive aspect, but affective and psychomotor as well. This is an eye opening for teachers and students regarding one's latent and hidden capabilities, which play vital roles in one's life especially in teaching and learning. According to Armstrong (1994) and Abd Fatah (1998), student who behaves differently while he is in class is actually showing a good sign that he has multiple intelligences, which will help improve the potentials of the brain.

In daily classroom teaching activities, teachers should apply thinking skills in all the six levels of Bloom's Taxonomy which involve five aspects, namely knowledge, understanding, application, analysis, evaluation and designing. All of the six levels of difficulties need to be used optimally in order to increase students' thinking skills in learning History. Hence, History class is not the place for students to simply receive whatever information given to them, the class should be the place for students to digest, revise, analyse and find answers of an important historical event. Low achievement students can also become excellent students if they are given proper guidance and fair chances through suitable ways to tap their potentials resulting to a positive learning situation.

When all level of difficulties are used, they stimulate students' thinking skills even though they were once categorised as low achievers. The fact is, if low achievers experience the same teaching and learning process suitable to their ability, they too can succeed (Bruer, 1993). Integrated multiple intelligence together with exposure and practices ensure those students are not left behind.

Based on the research findings, it is recommended that students' multiple intelligences need to be tapped and digested for their own benefits particularly in learning History subject. Multiple-intelligence should be applied effectively among students through various effective activities and methods to increase students' motivation to learn History.

Multiple intelligence should be integrated in various methods and activities, such as by using maps, pictures, and thinking map. Other activities involve audio visual such as movies, patriotic songs, acting and more. All of the the eight types of intelligence can be integrated in all of those activities. For example, the teacher puts a blank map in front of the class and asks students to search and get more information from the text books; later the information is then transferred onto the map. At the same time, music can be played or a student can be selected as a narrator to narrate the historical event at the place where students have to indicate on the map. A well-integrated multiple intelligences for example kinesthetic, spatial, and verbal linguistic, and musical, would easily help students to explore each topic that they are interested to learn.

Apart from that, teachers can prepare matching activity. The example of the lesson is: a teacher provides the flags of each state of the country, students have to match the flags with the states, level up its difficulty by asking students to name the rulers, the state leaders and write meanings of the flag's colours matching with the state's anthem or official song played by the teacher. This activity can be held as an individual or group activity. These activities have applied visual-spatial, interpersonal, verbal-linguistic and musical intelligence. And at the same time the exercise has also applied the six levels of Bloom's taxanomy. 
Musical intelligence can be applied during the induction set, such as the teacher plays the states' song and then asks students to write or complete lyrics of the songs. The lesson would be more interesting and fun when students are asked to listen to the song and sing the song together. Low achievement students prefer a relaxing atmosphere like this, as they gain tremendous benefits through these activities.

After the teacher explains the contents of the lesson, students can be asked to describe the topic in the manner of a song. This can improve students' memory on the topic they have studied. As an example, when they study the Hijrah topic, the teacher asks students to sing a nasyid entitled "Hijrah" and then explains the topic based on the lyric. So, finding the meaning and concepts of Hijrah would make the lesson to be more fun and exciting.

Kinesthetic, interpersonal and intrapersonal intelligences can be applied when students are given the chance to role modelling the notable historical figures. The activities are role playing the historical figures and narrating the story of the people. This can attract students' interests and increased students' knowledge on the notable historical figures. It also helps students to remember the lesson by associating it with the people. Teacher can also provide a set of incomplete dialog where students have to fill in some blanks with the missing words based on the information in the text book. Students can also dramatize the dialog when it is completed. This is another way to help students remember the lesson and teacher has indeed integrated multiple ways of teaching and learning History.

Logic-mathematic intelligence in teaching History can be done by asking students to arrange the sequence of historical events, to complete a time line based on years. Arranging and sequencing historical events based on the years would help students to better understand the events. It would be better if the teacher can ask students to sequence the events choronologically based on visual materials. Learning with pictures and visual aids is recognised as able to facilitate mental process in recieving and remembering history facts, in having better understanding of the events, and developing the levels of difficulties of the Bloom's taxanomy. In completing time line with significant information from the text book, students are actually using their mathematical intelligence particularly when they have to record or document historical events in a graphic manner, which consequently would help them to remember the facts even better.

Word game is an example of activities to apply verbal linguistic intelligence. It can be conducted as an activity for the induction set or enrichment exercise. The examples of word games are cross word puzzle and word search/word mace, which can only be solved by searching information from the text book. Other enjoyable activities that can be used in schools are reading and writing storylines, composing poetries and story telling assissted by sound and word images. The subject teacher can also prepare a speech or script on an event. These examples of activities not only help students to remember facts but also help them to use their intelligence.

\section{Conclusion}

Results of this study showed that low achievers in the History subject are capable to improve their achievement if they are given various types of supports and professional guidance. Many factors affected students' motivation to learn History Subject as Learning History subject requires students to master historical thinking skills which are vital elements for improving academic attainment. Supportive learning ecology is essential for boosting students' motivation to actively engage in learning activities. Data from this study suggest that school community and family members have to be more proactive in designing, implementing and monitoring educational activities for improving students' interest in learning all academic subjects. In addition, implementation of new approaches in various contexts and situations should be conducted in a very professional way as it has a direct impact on students' motivation and wellbeing. Teaching strategies should be appropriate by taking into consideration of students' cognitive ability, especially of those low achievers. Therefore, integrated multiple intelligence (IMI) is one of the approaches to be implemented for low achievement students. IMI provides ample opportunities for students to learn based on their own abilities, so they would be more comfortable and fun to learn, at the same time teachers are helping students to acquire the lesson well. Teaching and learning is indeed a challenging process. However, it may be relevant to highlight that there is no teaching strategy that is effective for any situations. This highlights the importance of action research and professional development programmes for improving teaching abilities and competences.

\section{References}

Abbas, M., \& Khurshid, F. (2013). Motivational Techniques and Learners 'Academic Achievement at Primary Level. Global Journal of Human Social Science Linguistics \& Education, 13(3).

Abd Fatah, H. (1998). Comprehensive Thinking. Kuala Lumpur: Utusan Publications \& Distributors Sdn Bhd. Abd Rahim, A. R. (1989). KBSM History Teaching Strategies. Kuala Lumpur: Fajar Bakti. 
Abdul Hakim@Abdul Khakin Samuri. (2004).Secondary school students attitudes toward History subject. Master Thesis. Universiti Kebangsaan Malaysia.

Ahmad, A. R., Awang, M. M., Seman, A. A, Abdullah, R. (2013). The Skills of Using History Textbooks in Secondary School. Asian Social Science, 9(12), 229-236. http://dx.doi.org/10.5539/ass.v9n12p229

Armstrong, T. (1994). Multiple Intelligences In the Classroom. Alexandria, Virginia: ASCD.

Atta, M. A., \& Jamil, A. (2012). Effects Of Motivation And Parental Influence on the Educational Attainments Of Students at Secondary Level. Academic Research International, 2(3), 427-431.

Awang, M. M. Ahmad, A. R., \& Ali, M. M. (2013). Professional Teachers' Strategies for Promoting Positive Behaviour in Schools. Asian Social Science, 9(12), 205-211. http://dx.doi.org/10.5539/ass.v9n12p205

Awang, M. M., Ahmad, A. R., Bakar, N. A., Ghani, S. A., Yunus, A. N. M., Ibrahim, M. A. H., .. Awang, M. M. (2013). Students' Attitudes and their Academic Performance in Nationhood Education. International Education Studies, 6(11), 21-28.

Center of Curriculum Development. (2001). Pedagogical Modules for the application of Multiple Intelligence Theory in Teaching and Learning. Ministry of Education. Malaysia.

Davies, C. J. (1975). The Slow Learners in the Secondary School. New York: Warlock Educational

Dunlosky, J. (2013). Improving Students' Learning With Effective Learning Techniques: Promising Directions From Cognitive and Educational Psychology. Psychological Science in the Public Interest, 14(1), 4-58. http://dx.doi.org/10.1177/1529100612453266

Entwistle, N. J., \& Wilson, J. D. (1970). Personality, Study Methods and Academic Performance. University Quarterly, 24, 147-156.

Fischer, H., \& Virgillito, A. (2012). Academic Motivation of Students - The German Case. Discussion Paper Nr. 2-1012. Germany: Dortmund

Gardner, H. (1983). Frames of Mind: The Theory of Multiple Intelligence. New York: Harper \& Row.

Gardner, H. (1989). To Open Minds: Chinese clues to the dilemma of contemporary education. New York: Basic Books.

Gardner, H. (1991). The Unschooled Mind: How children think and how schools should teach. New York: Basic Books.

Gardner, H. (1993). Frames of Mind: The theory of multiple intelligences. New York: Basic Books.

Gardner, H. (1999). Intelligence Reframed. Multiple intelligences for the 21st century, New York: Basic Books.

Gardner, H. (1999). The Disciplined Mind: Beyond Facts And Standardized Tests, The K-12 Education That Every Child Deserves. New York: Simon and Schuster

Gottfried, A. E. (1985). Academic Intrinsic Motivation in Elementary and Junior High School Students. Journal of Educational Psychology, 6, 631-645. http://dx.doi.org/10.1037/0022-0663.77.6.631

Griffin, D. (1978). Slow Learners: A Break in the circle, A Practical guide for the teachers. London: The Wobura Press.

Hasan, A. A., Hamzah, M. I., \& Awang, M. M. (2014). Inculcating Noble Values for Pre-Service Teachers. International Education Studies, 7(11), 111-119. http://dx.doi.org/10.5539/ies.v7n11p111

High, G. (1977). Teaching Slow Learners. London: Maurice Temple Smith Ltd.

Jacobson, L. T., \& Burdsal, C. A. (2012). Academic Performance in Middle School: Friendship Influences. Global Journal of Community Psychology Practice, 2(3), 1-12.

Lawrance, A. S. A., \& Vimala, A. (2012). School Environment and Academic Achievement of Standard IX Students. Journal of Educational and Instructional Studies in the World, 2(3), 210-215.

Lepper, M. R., Corpus, J. H., \& Iyenger, S. S. (2005). Intrinsic and Extrinsic Motivational Orientations in the Classroom: Age Differences and Academic Correlates. Journal of Educational Psychology, 97(2), 184-196. http://dx.doi.org/10.1037/0022-0663.97.2.184

Maharom, M. (1998). Analysing History Thinking Skill in the Curriculum for the lower secondary. Master Thesis. Universiti Kebangsaan Malaysia. 
Meichenbaum, D., \& Biemiller, A. (1998). Nurturing Independent Learner: Helping Student Take Charge Of Their Learning. Cambridge: Brookline Books.

Nor Zaiton, H. (2006). Attitudes and Motivation among Secondary School Students towards Learning the Malay proverbs. Project Paper. Universiti Kebangsaan Malaysia.

Omardin, H. A., \& Yunus, M. (1996). The Methods of Teaching History. Kuala Lumpur: Utusan Publication \& Distributors Sdn Bhd.

Phillips, J. A. (1993). Cognitive Teaching Strategies in improving academic achievement of low achievers. Challenges of Malaysian Education (Special ed.). Education Faculty. Universiti Malaya.

Pierce, C. (1998). Importance of Classroom Climate for at risk Learners. Journal of Educational Research, 88(1), 37-42. http://dx.doi.org/10.1080/00220671.1994.9944832

Pintrich, P. R., \& De Groot, E. V. (1990). Motivational and Self-Regulated Learning Components of Classroom Academic Performance. Journal of Education Psychology, 82(1), 33-40. http://dx.doi.org/10.1037/00220663.82.1.33

Renganathan, L. (2013). A Comparative study on Effect of Jigsaw Puzzle Method among nursing students' academic level of performance at Oman Nursing Institute, Muscat. Indian Journal of Applied Research, 3(9), 180-182. http://dx.doi.org/10.15373/2249555X/SEPT2013/57

Roslan Md, I. (2007). The effectiveness of Teaching and Learning Modules towards low achievement students in the Economic Subject. Master Thesis. Universiti Kebangsaan Malaysia.

Sakhilah Shahkat, A. (1998). Student's Motivation: 6 Influencing Factors. Master Thesis. Universiti Kebangsaan Malaysia.

Salwani, D. (2003). The effectiveness of Teaching and Learning Modules towards low achievement students in the Form FOur History Subject. Research Project. Universiti Kebangsaan Malaysia.

Samira, B., \& Mohammad, J. R. (2013). An Investigation into the Relationship Between Teachers' Creativity and Students' Academic Achievement: A Case Study of Iran EFL Context. Middle-East Journal of Scientific Research, 14(12), 1576-1580.

Shahabuddin, H., Rohizani, Y., \& Mohd Zohir, A. (2007). Strategic Pedagogy and Effective Teching Techniques. Kuala Lumpur: PTS Profesional.

Sugiyono, S. (2007). Educational Reset. Bandung: Penerbit Rosda Karya.

TitiSolfitri. (2007). The Effects of Jigwas III Cooperative Learning towards Motivation and Mathematic Achievement among Secondary Students of Pekan Baru. Research Project.Universiti Kebangsaan Malaysia.

Wahab, J. A., Mansor, A. N., Awang, M. M., Ayob, N. M. (2013). Managing Learners' Behaviours in Classroom through Negative Reinforcement Approaches. Asian Social Science, 9(16), 61-73. http://dx.doi.org/10.5539/ ass.v9n16p61

Wan Rafeei, A. R. (1977). The Achievement of Motivational Education in Malaysia. Jurnal Pendidikan, 6, 40-43.

Zahara, A. \& Nik Azleena, N. I. (2007). The impacts of Action Research on History Teachers' Readiness to implement History Thinking Skills. Jurnal Pendidikan, 32, 119-137.

\section{Copyrights}

Copyright for this article is retained by the author(s), with first publication rights granted to the journal.

This is an open-access article distributed under the terms and conditions of the Creative Commons Attribution license (http://creativecommons.org/licenses/by/3.0/). 